\title{
On-site Labour Productivity of New Zealand Construction Industry: Key Constraints and Improvement Measures
}

Serdar Durdyev and Jasper Mbachu, (Massey University, New Zealand)

\begin{abstract}
Productivity is key to the survival and growth of any organisation, industry or nation. Some factors constrain the achievement of the set project objectives in the New Zealand building and construction industry and are responsible for the reported steady decline of productivity and performance. This study aims to identify the key constraints to on-site labour productivity and improvement measures. Using the descriptive survey method, views of some project managers, contractors and subcontractors in New Zealand were canvassed via pilot interviews and questionnaire surveys at the qualitative and quantitative data gathering stages, respectively. Multi-attribute technique was used to analyse the quantitative data. Results showed that the key external constraints to on-site labour productivity comprise, in order of decreasing impact, statutory compliance, unforeseen events and wider external dynamics. The internal constraints were found to have much higher impact on onsite productivity than the external factors. In order of diminishing levels of impact, the internal constraints comprise reworks, level of skill and experience of the workforce, adequacy of method of construction, buildability issues, and inadequate supervision and coordination. The factors underlying each broad category of external and internal constraints are reported. The relative levels of impact of the identified constraints are expected to guide the project team in addressing the constraints in a cost-effective manner.
\end{abstract}

Keywords: Construction management, Labour productivity, New Zealand construction industry, Performance improvement, Productivity constraints.

\section{Introduction}

Productivity enables an organisation to be competitive, achieve set goals, meet stakeholder value propositions and maintain strategic and financial health. At the industry level, productivity enables the sector to maintain satisfied clientele, attract investment, remain viable and contribute to the economic growth and well-being of the nation. For instance, the Department of Housing (DBH, 2008) observes that the level of activity and the productivity of the building and construction sector underpins New Zealand's economic recovery and growth, adding that "what happens in the building and construction sector has a 'multiplier effect' on the wider economy" (p. 6). Improvement in the productivity of the New Zealand construction industry is therefore of critical importance considering its $\$ 388$ billion worth of current building stock, excluding land (CSG, 2010) and its significant contribution - of approximately 5 percent - to the GDP (DBH, 2008).

It is against this background that the Report of the Building and Construction Sector Productivity Taskforce (BCSPT) (DBH, 2009, p. 2), that "productivity, especially labour productivity has been disappointing and is limiting the sector's ability to respond positively to change", should be seriously considered. The Report re-echoes the urgent need to address this worrisome development by asserting that "the performance and productivity of the sector is critical for the performance of the New Zealand economy". In an earlier study, Duncan (2002, p. 1) concludes that, "an improvement in 'efficiency' of the building and construction sector - defined as a reduction in the cost of work put in place - will have a positive effect on every other sector, and consequently on the national economy". 
Sufficient evidence suggests that on-site productivity measurements should be the basis for making productivity improvement decisions (Oglesby et al., 1989, McCullouch, 2007, Carlos and Paul, 2010). This study will focus on on-site productivity constraints, since addressing these constraints will provide the much-needed productivity improvement in the industry.

\section{Productivity in Context}

Productivity is a complex concept that could be interpreted in varied contexts depending on the objectives sought; the objectives in turn determine the parameters involved in its assessment in relation to the benchmark used for its comparison. At the macro-economic level, the Building and Construction Sector Productivity Taskforce (BCSPT, 2009) sees productivity as an industry's ability to convert inputs into outputs. Generally, productivity is a measure of how well resources are leveraged to achieve set objectives or desired outputs. This is a definition that fits well with different perspectives; it emphasizes creativity and innovation, which target achieving more outputs with less resource inputs by re-engineering the production or service delivery process and optimising the resource leverage. The benchmark for comparison is critically important because productivity outcome in itself is meaningless except if it can be compared with a benchmark. The comparison could be intraentity - i.e. comparing productivity outcomes within a given entity across a time period with a view to gaining insights into the implicit trend. It could also be inter-entities - i.e. comparing productivity outcomes across similar entities with a view to determining the relative levels of productivity of the entities at a snapshot or across a time horizon.

The objectives to be achieved, the resources employed, the measures adopted and the benchmarks used for comparison give rise to different definitions of or perspectives on productivity. The common threads in all definitions or contextual interpretations of productivity relate to:

- Effectiveness: i.e. how effective is the leveraging of the resources to achieve the set objectives? E.g. a system can be adjudged productive in effectiveness context, if the set objectives are achieved through effective resource leverage;

- Efficiency: i.e. in achieving the set objectives, how efficient was the utilization of the scarce resources in the implementation process?

Overall, an operational definition of productivity that fits well with the various approaches to defining the concept - which draws upon the output-input paradigm - is the amount or quantity of output of a process per unit of resource input'. This aligns with similar definitions by a number of authors (Tran and Tookey, 2011; Page, 2010; Enshassi, et al, 2007). Equation 1 summarises the key features embodied in this definition.

$$
\text { Productivity }=\frac{\text { Output }}{\text { Resource input }}
$$

Where: Output could be in units or dollar value of product or service, revenue generated or value added; resource input could be in units or dollar value relating to manpower (i.e. manhour), machinery (i.e. machine hour), materials (i.e. quantity), or money (i.e. dollar value).

The nature of the resource input or a combination of inputs also informs the type of productivity and the measures used to evaluate it as shown in Equation 1. The two most common types of productivity are the single-factor and multi-factor productivity; the former considers only one of the resource inputs as the denominator to Equation 1, while the latter considers all resource inputs for a more holistic perspective.

Durdyev, S and Mbachu, J (2011) 'On-site labour productivity of New Zealand construction industry: Key constraints and improvement measures', Australasian Journal of Construction Economics and Building, 11 (3) 18-33 


\section{Constraints to Onsite Labour Productivity}

Based on the input-output paradigm, Equation 1 shows that constraints to productivity could be one or more of the following categories:

1. Constraints to the quantity or dollar value of the outputs;

2. Constraints to the quantity or dollar value of inputs

3. A combination of the above.

From a strategic perspective, particularly as it pertains to the construction project implementation, constraints to productivity relate to the factors constraining the achievement of set project objectives. To this effect, several studies in the past have identified typical constraints to productivity in the construction industry. For instance, Wilkinson and Scofield (2010) identify the choice of procurement system as having significant impact on the achievement of time, cost and quality targets for a project. Mbachu and Nkado (2007) identify factors relating to the acts or omission of the key role players including clients, consultants and contractors, as well as project characteristics and external factors. The Egan (1998) Report, though focused on house building, points to several constraints including processes and overuse of materials, poor management of relationships and the workforce, unambitious targets and ineffective measurement of performance as some of the productivity constraints. As it relates to productivity, the central argument of the Egan Report is that without best practice procedures and measurable indicators to help monitor the progress of improvements, the mission to produce better projects (including improvement of productivity) will not be achievable due to faulty processes and lack of benchmarks. In the New Zealand context, Page (2010) identifies level of trade skills, project organisation and design detailing. The BCSPT Report (DBH, 2009) points to sector wide skill shortage, approach to procurement of construction projects, lack of innovation in the construction practices, and the impact of regulations as drivers of low productivity growth of the New Zealand building and construction sector between 1997 and 2008. The Report also identifies design problems, poor supervision and workmanship, and faulty materials as prime causes of defects and low productivity. However, the Report admits that the identified constraints are unlikely to explain fully the sector's poor productivity performance, and therefore calls for further research in this area.

At the industry level, the Department of Housing (DBH, 2008) identify further constraints to productivity and performance of the sector to include: 1 ) loss of skills and capacity owing to the economic downturns; 2) the way the Resource Management Act 1991 is applied, the significant costs and uncertainties it creates, and the lengthy process of land use decision under the Act; and 3) high development fees charged as infrastructure contributions under the Local Government Act 2002 and the RMA 1991.

From a more structured perspective, Enshassi et al (2007) classify factors affecting labour productivity into 10 groups: manpower, leadership, motivation, time, materials/tools, supervision, project, safety, quality and external factors. On the other hand Kazaz et al. (2008) group sub-factors influencing construction labour productivity under 4 main factors: organizational, economic, physical and socio-psychological factors. Page (2010) identifies other factors such as site and design specific characteristics, the organisation and size of firms, level of skills and poor design details. In a recent study, Tran and Tookey (2011) looked at the economic factors impacting on labour productivity of a number of subindustries in New Zealand; the authors found that the national inflation rates, construction employment and construction costs were the key determinants of the values of the productivity outputs (i.e. house and land prices) and inputs (i.e. labour and material costs). Tran and Tookey (2011) recommend further investigations of productivity of the industry as a whole looking at wider influencing factors. 


\section{Gaps in the Literature and the Research Objectives}

While past studies have identified various factors affecting productivity at all levels of the construction industry, the factors are not prioritised in terms of their relative levels of impact on productivity. The prioritisation is important because it would enable the project team to leverage the limited resources at their disposal to addressing those factors that have higher impact on productivity. This study aims to contribute to filling this gap. The specific objectives of the study are as follows:

1. To identify the key constraints to on-site labour productivity in the New Zealand construction industry.

2. To analyse the relative levels of impact of the identified onsite labour productivity constraints.

3. To explore measures for improving productivity levels in the industry.

\section{Research Method}

The study relied on experienced-based feedback on the key on-site productivity constraints from those at the forefront of project implementation - the consultants, contractors and subcontractors - as the source of the primary data. The descriptive survey was therefore chosen as the most appropriate research method (Leedy and Ormrod, 2009; Mbachu, 2008; Cooper and Schindler, 2006). This involved the use of pilot interviews and questionnaire surveys at the qualitative and quantitative data gathering stages, respectively. At the qualitative data stage, a convenience sample of nine interviewees comprising three each of project managers, contractors and subcontractors were interviewed on the constraints to onsite labour productivity in New Zealand. The constructs generated were used to design a questionnaire which was subsequently pretested to ensure its clarity and relevance. The feedback formed the basis for redesigning the content and structure of the questionnaire so as to improve its appeal and ensuing survey response rate.

The original intention at the quantitative survey stage was to use random stratified sampling techniques to collect representative samples from the three sampling frames comprising the membership directories of the Association for Consulting Engineers New Zealand Inc (ACENZ), the New Zealand Contractors' Federation (NZCF) and the New Zealand Specialist Trade Contractors Federation (NZSTCF). However, it was not possible to obtain the membership directories due to privacy issues. The researchers therefore resorted to the use of online search engines and the Yellow Pages to obtain a list of two hundred and fifty contacts comprising fifty project management consultants, one hundred and twenty contractors and eighty subcontractors in the three major cities of New Zealand, namely, Auckland, Wellington and Christchurch. The prospective participants were first contacted by phone to request their participation in the survey. Only one hundred and fifty contacts comprising thirty project management consultants, eighty contractors and forty subcontractors - out of the two hundred and fifty potential respondents were willing to participate in the survey. Emails were subsequently sent to the willing participants with a link to the questionnaire online requesting them to respond by completing the online survey within a specified timeframe in order to maintain anonymity of feedback. The ten to fifteen minute response to the online survey involved rating the constructs using a five-point Likert scale, but with provision for further inputs on additional constructs which were not included in any given subset.

\section{Data Analysis}

The multi-attribute analytical technique was used to analyse the ratings of the respondents. This approach was recommended in past studies (Mbachu and Nkado, 2007; Chang and Ive, 2002) as the appropriate analytical approach to group ratings of the variables in a given set. The analysis involved the computation of the Mean Rating (MR), which is the average or

Durdyev, S and Mbachu, J (2011) 'On-site labour productivity of New Zealand construction industry: Key constraints and improvement measures', Australasian Journal of Construction Economics and Building, 11 (3) 18-33 
representative rating point for the collective ratings made for each variable in the subset. Equation 2 shows the computation for the MR as provided by Mbachu and Nkado (2007).

$$
\mathrm{MR}_{\mathrm{j}}=\sum_{\mathrm{k}=1}^{5}\left(\mathrm{R}_{\mathrm{p}_{\mathrm{jk}}} \times \% \mathrm{R}_{\mathrm{jk}}\right)
$$

Where:

- $\mathrm{MR}_{\mathrm{j}} \quad=\quad$ Mean Rating for constraint factor $j$;

- $\mathrm{R}_{\mathrm{pjk}}=$ Rating point $k$ (ranging from 1-5);

- $\% \mathrm{R}_{\mathrm{jk}}=\quad$ Percentage response to rating point $k$, for constraint factor $j$.

\section{Level of Significance of the Constraint Factors}

Based on the MR values, the most significant constraint factor in a subset is one with the highest MR value. The constraint factor having an average or higher level of impact on onsite labour productivity is considered significant as shown in Equation 3.

$$
\begin{array}{ll}
\text { Significant constraint factor: } & M R \geq 2.5 \\
\text { Non-significant constraint factor: } & M R<2.5
\end{array}
$$

Where: $1<\mathrm{MR}<5$ on a rescaled 5 -point Likert rating scale.

It should be noted that the middle of the 5-point Likert scale is 3 . However, on a transformed interval scale used in the computations, 2.5 is the lower end of the re-scaled middle band hence its use as the threshold of significance.

\section{Results and Discussions}

\section{Survey Responses}

Out of a total of 250 initial invitations, only thirty seven usable responses were received by the cut-off date; this represented about 15 percent usable response rate. The thirty seven usable responses were from project manager consultants (39\%), contractors $(53 \%)$ and subcontractors $(8 \%)$. The feedback was therefore biased towards the contractors' views with very little inputs from the subcontractors. The follow-up reminders showed that the respondents, especially the subcontractors were busy chasing new tenders on account of the current economic recession and so had no time to participate in the survey.

The demographic profiles of the respondents showed that the majority - 77 percent - had at least 15 years work experience in the construction industry, 83 percent occupied high ranking positions in their respective organisations as directors, managers, or associate directors. The feedback was therefore from highly experienced subjects who had the authority to make important decisions about productivity in their respective organisations. This adds to the quality and reliability of the feedback, though the findings could not be generalised beyond the data points due to the non-representation of the target populations.

\section{Key constraints to onsite labour productivity in New Zealand}

At the pilot interviews, the recurring constructs mentioned by or alluded to by the interviewees as key internal and external constraints to onsite labour productivity in the New Zealand construction industry were classified under broad categories. Figure 1 shows the external constraints, which comprise three broad categories: statutory compliance, unforeseen events and other external forces. Figure 2 presents the internal constraints, which comprise five broad categories: project finance, workforce, technology/ process, project characteristics, and project management. The subcomponents of each category are 
listed in the figures. In total, fifty-six factors were identified in the eight broad categories of internal and external constraints.

\begin{tabular}{|c|c|c|}
\hline & xternal Constraints & \\
\hline $\begin{array}{l}\text { Statutory Compliance: } \\
\text { 1) Health \& Safety in } \\
\text { Employment Act; } \\
\text { 2) Resource Management Act; } \\
\text { 3) Local Authority Bylaws; } \\
\text { 4) Construction Contracts Act; } \\
\text { 5) Building Act/Building } \\
\text { Consent/Building Regulations; } \\
\text { 6) Employment Relations Act; } \\
\text { 7) Consumer Guarantees Act; } \\
\text { 8) Fair Trading Act; } \\
\text { 9) Arbitration Act; }\end{array}$ & $\begin{array}{l}\text { Unforeseen Events: } \\
\text { 1) Inclement Weather; } \\
\text { 2) Ground Conditions } \\
\text { necessitating revisions; } \\
\text { 3) On-site Accidents/ } \\
\text { Acts of God; } \\
\text { 4) Natural Disasters; }\end{array}$ & $\begin{array}{l}\text { Other External Forces: } \\
\text { 1) Inflation/ Fluctuations in Material } \\
\text { Prices; } \\
\text { 2) Fluctuations in Exchange Rate; } \\
\text { 3) Energy Crises/Costs; } \\
\text { 4) Interest Rate/Cost of Capital; } \\
\text { 5) Market Conditions and Level of } \\
\text { Competitions in the Industry for Jobs; } \\
\text { 6) Frequent Changes in Government } \\
\text { Policies/Legislations Impacting on } \\
\text { Construction; } \\
\text { 7) Rapid Technological Advances; } \\
\text { 8) Increase in industry or Society-wide } \\
\text { Litigations/Adversarial Relations; }\end{array}$ \\
\hline
\end{tabular}

Figure 1 External constraints to construction on-site productivity

\begin{tabular}{|c|c|c|c|c|}
\hline & Inte & nal Constraints & & \\
\hline $\begin{array}{l}\text { Project Finance: } \\
\text { 1) Late payments; } \\
\text { 2) Reworks; } \\
\text { 3) Under valued } \\
\text { work/poor } \\
\text { estimation; } \\
\text { 4) Dispute and } \\
\text { litigation costs; } \\
\text { 5) Lenders' high } \\
\text { interest charges; } \\
\text { 6) High insurance } \\
\text { premiums. } \\
\text { 7) Inadequate } \\
\text { supply or high cost } \\
\text { of needed } \\
\text { resources: money, } \\
\text { labour, etc. }\end{array}$ & $\begin{array}{l}\text { Workforce: } \\
\text { 1) Level of } \\
\text { commitment; } \\
\text { 2) Level of } \\
\text { empowerment; } \\
\text { 3) Level of skill } \\
\text { and experience } \\
\text { 4) Level of } \\
\text { familiarity with } \\
\text { current job and } \\
\text { conditions: } \\
\text { 5) Level of } \\
\text { involvement of } \\
\text { direct labour or } \\
\text { subcontract; } \\
\text { 6) Workforce } \\
\text { Absenteeism; } \\
\text { 7) Level of staff } \\
\text { turnover/churn } \\
\text { rate; } \\
\text { 8) Health of the } \\
\text { workforce; }\end{array}$ & $\begin{array}{l}\text { Technology/ } \\
\text { Process: } \\
\text { 1) Suitability or } \\
\text { adequacy of: } \\
\text { Plant \& } \\
\text { equipment; } \\
\text { 2) Method of } \\
\text { construction; } \\
\text { 3) Technology } \\
\text { employed; } \\
\text { 4) Lack of } \\
\text { awareness of or } \\
\text { training on new } \\
\text { technologies; } \\
\text { 5) Resistance to } \\
\text { accept new } \\
\text { technologies; } \\
\text { 6) Inadequate IT } \\
\text { infrastructure and } \\
\text { application in } \\
\text { construction } \\
\text { industry; }\end{array}$ & $\begin{array}{l}\text { Project } \\
\text { Characteristics: } \\
\text { 1) Site } \\
\text { conditions: } \\
\text { access, subsoil; } \\
\text { topography; } \\
\text { 2) Project } \\
\text { complexity; } \\
\text { 3) Buildability } \\
\text { issues; } \\
\text { 4) Site location } \\
\text { and } \\
\text { environment; } \\
\text { 5) Type of } \\
\text { procurement } \\
\text { adopted; }\end{array}$ & $\begin{array}{l}\text { Project } \\
\text { Management: } \\
\text { 1) Adequacy of } \\
\text { planning and risk } \\
\text { management } \\
\text { process; } \\
\text { 2) Coordination; } \\
\text { supervision; } \\
\text { performance } \\
\text { monitoring \& } \\
\text { control; } \\
\text { 3) Project } \\
\text { organisational } \\
\text { culture; } \\
\text { 4) Relationship } \\
\text { management; } \\
\text { 5) Competencies of } \\
\text { the project team; } \\
\text { 6) Project } \\
\text { management style; } \\
\text { 7) Frequency of } \\
\text { design changes; } \\
\text { 8) Client's over } \\
\text { influence on the } \\
\text { construction } \\
\text { process; }\end{array}$ \\
\hline
\end{tabular}

Figure 2 Internal constraints to construction on-site productivity

Durdyev, S and Mbachu, J (2011) 'On-site labour productivity of New Zealand construction industry: Key constraints and improvement measures', Australasian Journal of Construction Economics and Building, 11 (3) 18-33 
At the questionnaire survey stage, the relative levels of impact of the broad categories and the subcomponents in each set were rated by the respondents to determine the significant and non-significant factors. The results in Table 1 show the most significant factors under each broad category; the analyses were made in the following subsections under each broad category.

\section{Broad category of constraints:}

\section{Internal constraints}

\begin{tabular}{l|l|}
\hline A & Project finance: \\
\hline B & Workforce: \\
\hline C & Technology/process: \\
\hline D & Project characteristics: \\
\hline E & $\begin{array}{l}\text { Project management/ project team } \\
\text { characteristics: }\end{array}$ \\
\hline
\end{tabular}

\section{External constraints}

\section{Subcomponent having the highest level of impact on on-site labour productivity}

Rework

Level of skill and experience of the workforce

Adequacy of method of construction

Buildability issues

Coordination, supervision, performance monitoring and control

\begin{tabular}{l|l|}
\hline A & Statutory compliance: \\
\hline B & Unforeseen events: \\
\hline C & $\begin{array}{l}\text { Other external forces (economical, political, } \\
\text { etc.): }\end{array}$ \\
\hline
\end{tabular}

Resource Management Act

Ground conditions necessitating revisions

Boom-bust cycles, market conditions and level of competitions in the industry for jobs

Table 1 Subcomponents having the highest level of impact on productivity under the respective broad categories

\section{Project Finance related Constraints}

The relative levels of impact of the sub-factors under the project finance broad category of on-site labour productivity constraints are analysed in Table 2. Results show that rework has the most significant impact on on-site labour productivity under this category with the highest MR value of 3.63. This result agrees with the findings of other authors (Burati et al. 1992; Cooper, 1993), who argued that the delays and costs associated with rework in construction have profound impact on productivity. In another study (Love et al. 1999, 2000), it was found that the cost of rework ranged from 2 to 12 percent of the total contract value. To minimize the problem of rework in the New Zealand construction industry, Page (2010) suggests the use of quality management systems and improvement in skills training, particularly for onsite management and the management of multi-projects at the firm level. The next most influential factor is under-valued work or poor estimation at the tender price. To guard against this, Henriod (2010) recommends the use of efficient tendering strategy involving a team approach to scrutinizing the tender documents for pitfalls and the pricing of the risks at pre-bid meetings. The involvement of the specialist trades and all key staff at these meetings helps to ensure that no important cost items are omitted and that the risks are properly priced.

\section{Workforce related Constraints}

Table 3 represents the analysis of the relative levels of impact of the sub-factors under the workforce broad category of on-site labour productivity constraints. Level of skill and experience of the workforce was rated as the subcomponent having the highest level of impact on onsite labour productivity. This result is consistent with some earlier findings (Alinaitwe 2007; Mojahed and Aghazadeh 2007) that the level of skill and experience of the workforce is the key determinant of onsite labour productivity and performance. The next most influencing factor is the level of motivation or commitment of the workforce. This also concurs with Henriod's (2010) conclusion that a happy team and improved work attitude can

Durdyev, S and Mbachu, J (2011) 'On-site labour productivity of New Zealand construction industry: Key constraints and improvement measures', Australasian Journal of Construction Economics and Building, 11 (3) 18-33 
result in tremendous improvement in labour productivity. Henriod opines that high level of workforce motivation and commitment can be achieved through job security, effective reward system, culture of openness, trust and loyalty and the involvement of the people at the coalface in the decision making process.

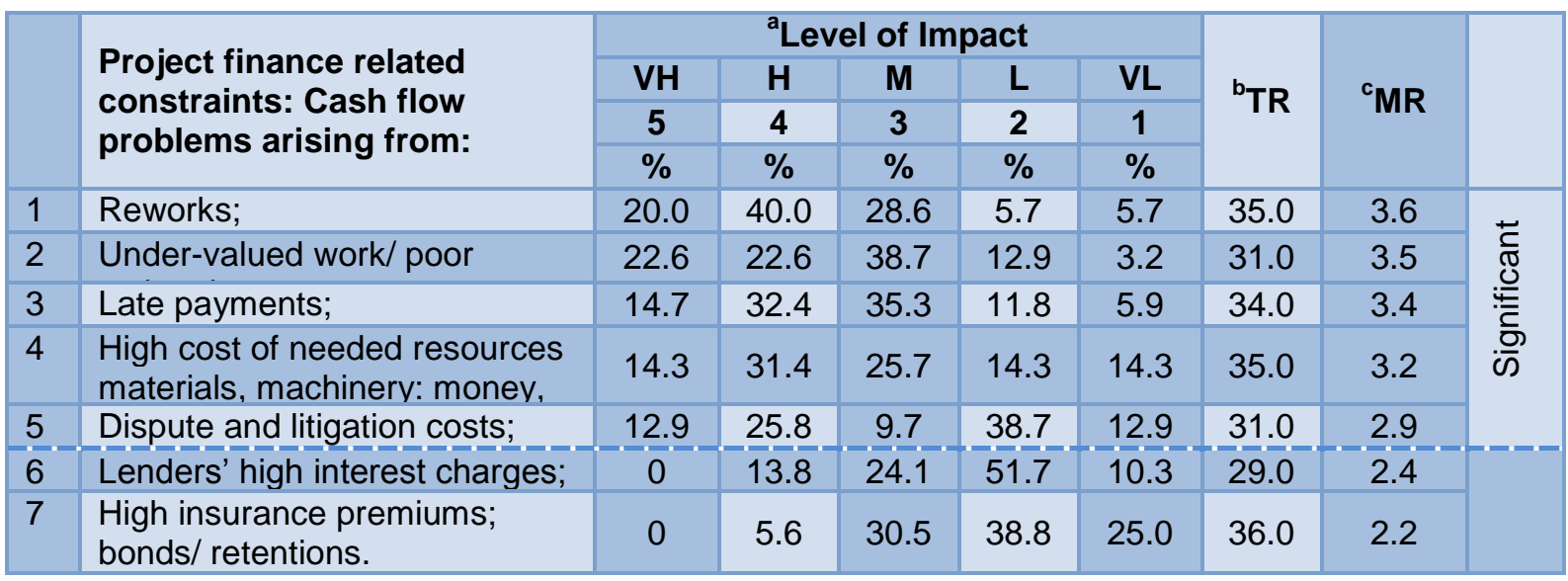

Table 2 Productivity constraints related to project finance

Notes: a) Levels of Impact: VH = Very high (5), $H=$ High (4), $M=$ Medium (3), L = Low (2), VL = Very low (1). b) $\mathrm{TR}=$ Total responses; $\mathrm{c}$ ) MR = Mean rating (see Equation 2)

\begin{tabular}{|c|c|c|c|c|c|c|c|c|c|}
\hline & \multirow{4}{*}{$\begin{array}{l}\text { Workforce: productivity } \\
\text { constraints arising from: }\end{array}$} & \multicolumn{5}{|c|}{${ }^{\text {a }}$ Level of Impact } & \multirow{4}{*}{${ }^{\mathrm{b}} \mathrm{TR}$} & \multirow{4}{*}{${ }^{\mathrm{c}} \mathrm{MR}$} & \\
\hline & & VH & H & M & $\mathbf{L}$ & VL & & & \\
\hline & & 5 & 4 & 3 & 2 & 1 & & & \\
\hline & & $\%$ & $\%$ & $\%$ & $\%$ & $\%$ & & & \\
\hline 1 & $\begin{array}{l}\text { Level of skill and experience of } \\
\text { the workforce; }\end{array}$ & 25.7 & 40.0 & 25.7 & 8.6 & 0 & 35.0 & 3.8 & \\
\hline 2 & $\begin{array}{l}\text { Level of motivation/ } \\
\text { commitment; }\end{array}$ & 20.0 & 40.0 & 22.9 & 14.3 & 2.9 & 35.0 & 3.6 & $\stackrel{\sim}{\sim}$ \\
\hline 3 & $\begin{array}{l}\text { Level of familiarity with current } \\
\text { job and conditions; }\end{array}$ & 8.6 & 45.7 & 31.4 & 8.6 & 5.7 & 35.0 & 3.4 & $\stackrel{\wedge}{\stackrel{\wedge}{\mathfrak{r}}}$ \\
\hline 4 & $\begin{array}{l}\text { Level of empowerment } \\
\text { (training and resourcing); }\end{array}$ & 11.4 & 42.9 & 22.9 & 22.9 & 0 & 35.0 & 3.4 & 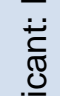 \\
\hline 5 & $\begin{array}{l}\text { Level of involvement of direct } \\
\text { labour or subcontract; }\end{array}$ & 11.8 & 29.4 & 35.3 & 23.5 & 0 & 34.0 & 3.3 & 宸 \\
\hline 6 & Workforce absenteeism; & 8.8 & 17.7 & 44.1 & 23.5 & 5.9 & 34.0 & 3.0 & \\
\hline 7 & Level of staff turnover & 2.9 & 20.0 & 42.9 & 25.7 & 8.6 & 35.0 & 2.8 & \\
\hline 8 & Health of the workforce; & 0 & 21.2 & 42.4 & 30.3 & 6.1 & 33.0 & 2.8 & \\
\hline
\end{tabular}

Table 3 Productivity constraints related to workforce

Notes: a) Levels of Impact: VH = Very high (5), $\mathrm{H}=$ High (4), $\mathrm{M}=$ Medium (3), L = Low (2), VL = Very low (1). b) $\mathrm{TR}=$ Total responses; $\mathrm{c}$ ) MR = Mean rating (see Equation 2)

\section{Technology/ Process related Constraints}

Analysis of the sub-factors under the technology/ process related broad category of onsite labour productivity constraints is presented in Table 4 . The majority of the respondents rated the adequacy of method of construction as having the greatest impact on onsite labour productivity. This is consistent with conclusions in previous studies (Alinaitwe et al. 2007; Sanders and Thomas, 1993) that the method adopted in the construction process has far reaching implications on productivity and performance of the construction crew. However, the method depends on the design and what the owner or the engineer is willing to approve as the appropriate method in the circumstances. Page (2010) recommends the use of modern design and construction methods such as modularisation and prefabrication and the avoidance of one-off designs. Though rated as the least significant in the set, Knutson et al. (2009) argue that the layout of the site is one of the most obvious of the impacts on

Durdyev, S and Mbachu, J (2011) 'On-site labour productivity of New Zealand construction industry: Key constraints and improvement measures', Australasian Journal of Construction Economics and Building, 11 (3) 18-33 
productivity. Careful planning and location of the contract preliminaries could therefore ensure effective workflow and construction speed resulting in improved onsite productivity.

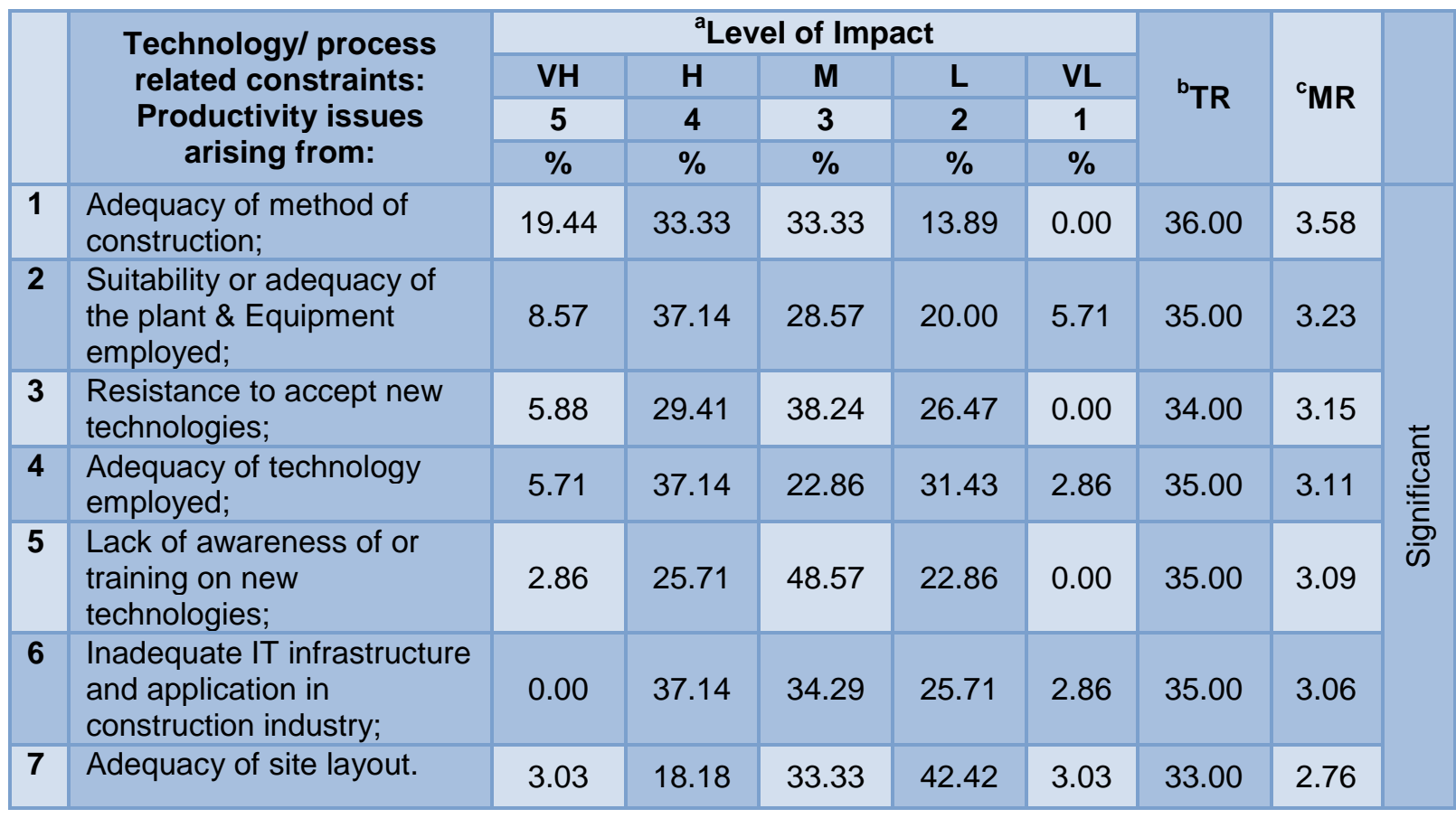

Table 4 Productivity constraints related to technology/ process

Notes: a) Levels of Impact: VH = Very high (5), $\mathrm{H}=$ High (4), $\mathrm{M}=$ Medium (3), L = Low (2), VL = Very low (1). b) $\mathrm{TR}=$ Total responses; $\mathrm{c}$ ) MR = Mean rating (see Equation 2).

\section{Project Characteristics}

Analysis of the subcomponents under the project characteristics set of constraints is presented in Table 5. Results show that buildability issues have the highest level of impact on onsite productivity. This finding support the conclusions of several studies (Jarkas, 2010; Lam and Wong 2009; Saghatforoush et al. 2009; Lam et al. 2007) that buildability issues, especially where design details are lacking, could slow down onsite work progress.

\begin{tabular}{|c|c|c|c|c|c|c|c|c|c|}
\hline & \multirow{4}{*}{$\begin{array}{l}\text { Project characteristics } \\
\text { related constraints: } \\
\text { Productivity issues } \\
\text { arising from: }\end{array}$} & \multicolumn{5}{|c|}{${ }^{\text {aLevel of Impact }}$} & \multirow{4}{*}{${ }^{\mathrm{b}} \mathrm{TR}$} & \multirow{4}{*}{${ }^{c} \mathrm{MR}$} & \\
\hline & & VH & $\mathbf{H}$ & $\mathbf{M}$ & $\mathbf{L}$ & VL & & & \\
\hline & & 5 & 4 & 3 & 2 & 1 & & & \\
\hline & & $\%$ & $\%$ & $\%$ & $\%$ & $\%$ & & & \\
\hline 1 & Buildability issues; & 20.00 & 40.00 & 34.29 & 2.86 & 2.86 & 35.00 & 3.71 & \\
\hline 2 & $\begin{array}{l}\text { Project complexity: scale; } \\
\text { design; }\end{array}$ & 20.59 & 35.29 & 32.35 & 11.76 & 0.00 & 34.00 & 3.65 & \\
\hline 3 & $\begin{array}{l}\text { Site conditions: access, } \\
\text { subsoil; topography; }\end{array}$ & 17.65 & 41.18 & 20.59 & 20.59 & 0.00 & 34.00 & 3.56 & : \\
\hline 4 & $\begin{array}{l}\text { Site location and } \\
\text { environment; }\end{array}$ & 11.76 & 26.47 & 35.29 & 20.59 & 5.88 & 34.00 & 3.18 & $\bar{\omega}$ \\
\hline 5 & $\begin{array}{l}\text { Type of procurement } \\
\text { adopted. }\end{array}$ & 8.82 & 26.47 & 35.29 & 23.53 & 5.88 & 34.00 & 3.09 & \\
\hline
\end{tabular}

Table 5 Productivity constraints related to project characteristics

Notes: a) Levels of Impact: VH = Very high (5), $H=$ High (4), $M=\operatorname{Medium~(3),~L~=~Low~(2),~VL~=~Very~low~(1).~b)~}$ $\mathrm{TR}=$ Total responses; c) MR = Mean rating (see Equation 2).

Durdyev, S and Mbachu, J (2011) 'On-site labour productivity of New Zealand construction industry: Key constraints and improvement measures', Australasian Journal of Construction Economics and Building, 11 (3) 18-33 


\section{Project Management/Project Team Characteristics}

With the highest MR of 4.43 listed in Table 6, coordination, supervision, performance monitoring and control set of constraints was found to be the most influential on-site labour productivity constraint factor under project management/project team characteristics group. This result was supported by (Thomas and Sakarcan 1994) who found that supervision and proper coordination of subcontractors have the most significant impact on on-site labour productivity. (Abdul Kadir et al. 2005) put emphasize on coordination with subcontractors, which was ranked as one of the influential factors in the study. Furthermore Jergeas (2009) and KPMG (2009) argue that effective project integration management, comprising the activities that integrate, coordinate and bring together the various functions and multiple stakeholders, is the key to achieving onsite productivity and performance.

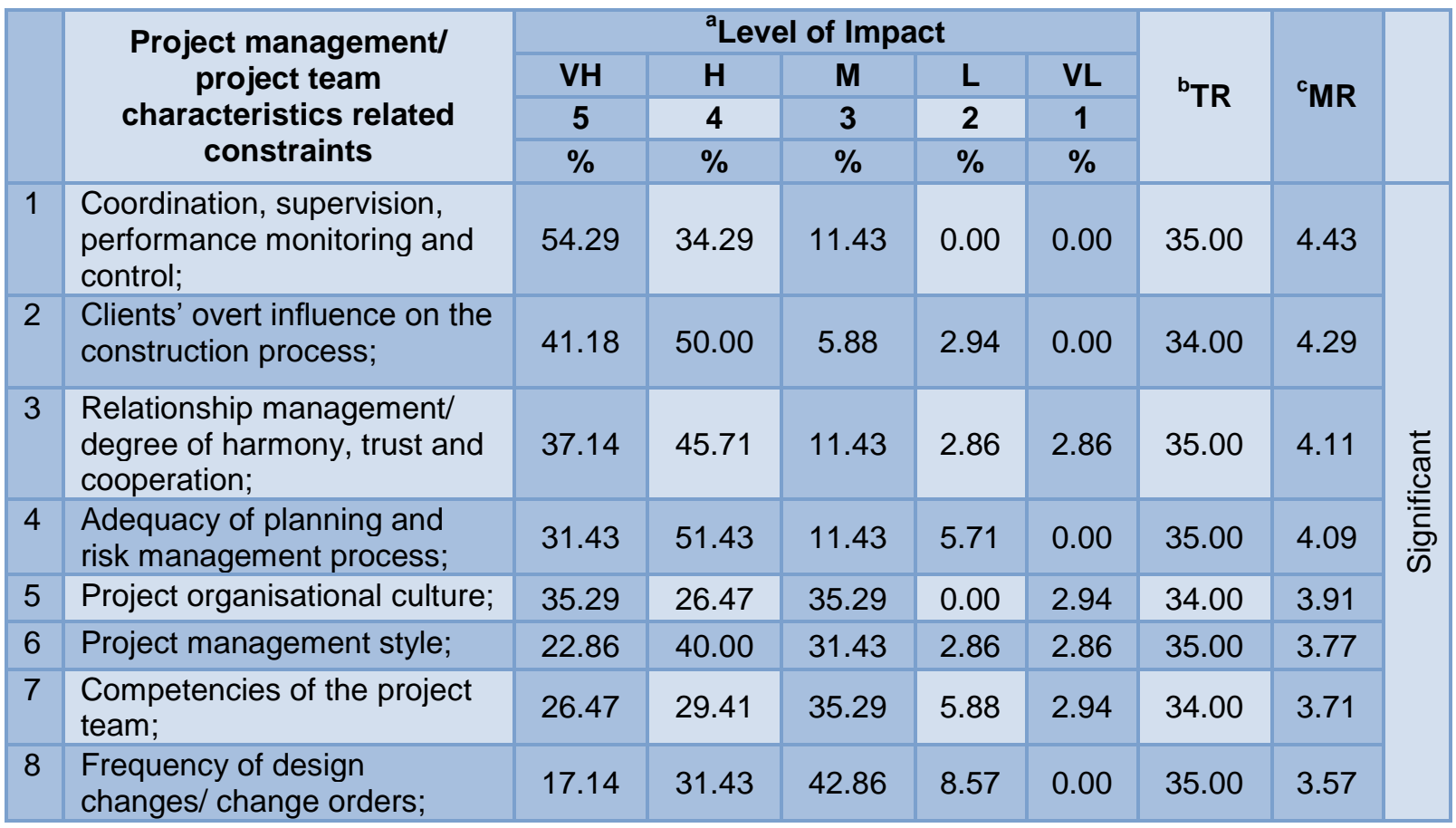

Table 6 Productivity constraints related to project management/ project team characteristics

Notes: a) Levels of Impact: VH = Very high (5), $\mathrm{H}=$ High (4), $\mathrm{M}=\operatorname{Medium}(3), \mathrm{L}=\mathrm{Low}(2), \mathrm{VL}=$ Very low (1). b) $\mathrm{TR}=$ Total responses; c) MR = Mean rating (see Equation 2).

\section{Statutory Compliance related Constraints}

Table 7 presents the analysis of the subcomponents of onsite productivity constraints related to statutory compliance. Compliance with the Resource Management Act (RMA) 1991 was rated as the most influential sub-factor. McShane (1996) hints that the impact of RMA on onsite labour productivity is profound especially in relation to resource content issues. The Department of Building and Housing (DBH, 2009) also notes that a number of industry leaders see regulation in its broadest sense as a critical factor constraining the industry productivity through increased compliance costs, limitation on activity, stifling of innovation and reduction of efficiency on worksites. As a mitigation measure, the Department believes that regulation should be used only sparingly and only if it is well designed. It is surprising to note that the Construction Contracts Act (CCA) 2002 - being the key legislation affecting construction contracts and operations - was rated very low by majority of the respondents. Perhaps, this could be due to the increased awareness of, and proactive response to, the Act since all parties must now abide by its provisions. Overall, having a working knowledge of the provisions of the legislations and regulations affecting their daily operations and taking proactive steps to their implementations would help the industry operators to sort out the compliance issues; the risk involved should be priced in the contracts.

Durdyev, S and Mbachu, J (2011) 'On-site labour productivity of New Zealand construction industry: Key constraints and improvement measures', Australasian Journal of Construction Economics and Building, 11 (3) 18-33 


\begin{tabular}{|c|c|c|c|c|c|c|c|c|c|}
\hline & \multirow{4}{*}{$\begin{array}{l}\text { Statutory compliance related } \\
\text { constraints: impediments arising } \\
\text { from compliance with: }\end{array}$} & \multicolumn{4}{|c|}{${ }^{\text {a Level of impact }}$} & \multirow{3}{*}{ VL } & \multirow{4}{*}{${ }^{\mathrm{b}} \mathrm{TR}$} & \multirow{4}{*}{${ }^{\mathrm{c}} \mathrm{MR}$} & \\
\hline & & VH & $\mathbf{H}$ & $\mathbf{M}$ & $\mathbf{L}$ & & & & \\
\hline & & 5 & 4 & 3 & 2 & & & & \\
\hline & & $\%$ & $\%$ & $\%$ & $\%$ & $\%$ & & & \\
\hline 1 & Resource Management Act & 8.82 & 29.41 & 38.24 & 17.65 & 5.88 & 34.00 & 3.18 & \\
\hline 2 & $\begin{array}{l}\text { Building Act/ Building Consent/ } \\
\text { Building Regulations }\end{array}$ & 9.09 & 27.27 & 27.27 & 33.33 & 3.03 & 33.00 & 3.06 & 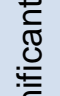 \\
\hline 3 & Health \& Safety in Employment Act & 2.63 & 23.68 & 44.74 & 10.53 & 18.42 & 38.00 & 2.82 & 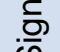 \\
\hline 4 & Local Authority Bylaws, & 0.00 & 20.59 & 38.24 & 35.29 & 5.88 & 34.00 & 2.74 & \\
\hline 5 & Employment Relations Act & 0.00 & 0.00 & 33.33 & 57.58 & 9.09 & 33.00 & 2.24 & \\
\hline 6 & Construction Contracts Act & 0.00 & 12.50 & 15.63 & 50.00 & 21.88 & 32.00 & 2.19 & \\
\hline 7 & Arbitration Act & 3.57 & 0.00 & 10.71 & 39.29 & 46.43 & 28.00 & 1.75 & \\
\hline 8 & Consumer Guarantees Act & 0.00 & 3.33 & 10.00 & 33.33 & 53.33 & 30.00 & 1.63 & \\
\hline 9 & Fair Trading Act & 0.00 & 3.45 & 6.90 & 34.48 & 55.17 & 29.00 & 1.59 & \\
\hline
\end{tabular}

Table 7 Productivity constraints related to statutory compliance issues

Notes: a) Levels of Impact: VH = Very high (5), $\mathrm{H}=$ High (4), $\mathrm{M}=$ Medium (3), L = Low (2), VL = Very low (1). b) $\mathrm{TR}=$ Total responses; $\mathrm{c}$ ) MR = Mean rating (see Equation 2).

\section{Unforeseen Events Group}

Table 8 shows that ground condition as a sub-factor under unforeseen events has the greatest impact on on-site labour productivity in New Zealand. This supports earlier finding (Clayton, 2001) that unforeseen subsurface conditions can affect adversely the construction process and productivity in terms of costs and completion time in a project of any scale.

\begin{tabular}{|c|c|c|c|c|c|c|c|c|c|}
\hline & & & ${ }^{a} \mathrm{Le}$ & el of in & pact & & & & \\
\hline & Productivity constraints & VH & H & $\mathbf{M}$ & $\mathbf{L}$ & VL & ${ }^{\mathrm{b}} \mathrm{TR}$ & ${ }^{\mathrm{c}} \mathrm{MR}$ & \\
\hline & related tc & 5 & 4 & 3 & 2 & 1 & & & \\
\hline & & $\%$ & $\%$ & $\%$ & $\%$ & $\%$ & & & \\
\hline 1 & Ground conditions; & 20.59 & 44.12 & 29.41 & 5.88 & 0.00 & 34.00 & 3.79 & \\
\hline 2 & Inclement weather; & 14.71 & 41.18 & 35.29 & 8.82 & 0.00 & 34.00 & 3.62 & 它 \\
\hline 3 & On-site accidents/ Acts of God; & 13.89 & 25.00 & 30.56 & 30.56 & 0.00 & 36.00 & 3.22 & $\begin{array}{c} \\
\end{array}$ \\
\hline 4 & Natural disasters; & 32.35 & 14.71 & 8.82 & 17.65 & 26.47 & 34.00 & 3.09 & \\
\hline
\end{tabular}

Table 8 Productivity constraints related to unforeseen events

Notes: a) Levels of Impact: VH = Very high (5), $H=$ High (4), $M=$ Medium (3), L = Low (2), VL = Very low (1). b) $\mathrm{TR}=$ Total responses; $\mathrm{c}$ ) MR = Mean rating (see Equation 2).

\section{Other External Forces Group}

Table 9 shows that, within the wider external factor broad category, the boom-bust cycles, market conditions and the level of competitions in the industry for scarce jobs was rated by the respondents as the set of factors having the highest impact on on-site labour productivity. This result is consistent with the findings of previous studies (Tran and Tookey, 2011; DBH, 2009; Davis 2008) which equally acknowledged the damaging effect of the boom-burst cycle on the New Zealand construction industry productivity and performance. The Building and Construction Sector Task Force (DBH, 2009) notes that better management of the boom-bust cycle will help improve skill development and retention, reduce waste and give greater confidence to industry participants, adding that "how the government plans and manages its procurement with the sector can have a crucial influence on the sector's ability to better manage the business cycle" (p. 9).

Durdyev, S and Mbachu, J (2011) 'On-site labour productivity of New Zealand construction industry: Key constraints and improvement measures', Australasian Journal of Construction Economics and Building, 11 (3) 18-33 


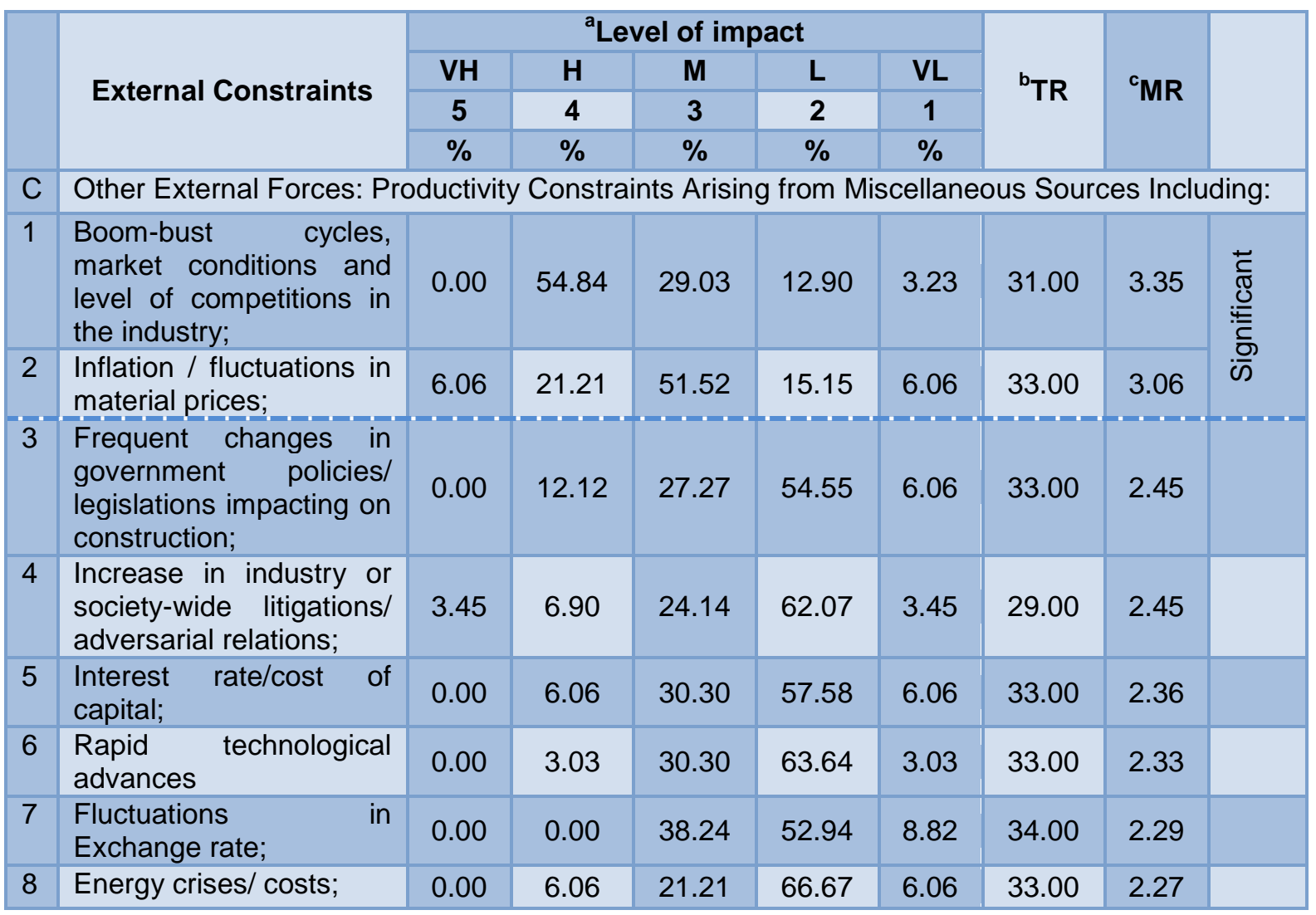

Table 9: Productivity constraints related to other external factors

Notes: a) Levels of Impact: VH = Very high (5), $H=$ High (4), $M=$ Medium (3), L = Low (2), VL = Very low (1). b) $\mathrm{TR}=$ Total responses; $\mathrm{c}$ ) MR = Mean rating (see Equation 2).

\section{Relative Levels of Impact of the Broad Categories of Productivity Constraints}

The relative levels of impact of the broad categories of onsite labour productivity constraints are analysed in Table 10. Results showed that all the eight broad categories of internal and external constraints are significant, having achieved MR values greater than the threshold value of 2.5 (see Equation 3). The internal constraint categories, comprising project finance, workforce, technology/process, project characteristics and project management, as calculated above, contribute 67 percent of the onsite labour productivity constraints, implying that the external constraints only contribute 33 percent. This result is in agreement with the findings of Fabling and Grimes (2008); the authors examine the relative importance of internal/ controllable and external/uncontrollable constraints to firms' performance and conclude that the differences in firm performance are explained in large measure by factors over which they have control rather than purely by exogenous factors. However, the relative contributions of the internal and external constraints should be interpreted on the ordinal, rather than interval scale. This is because the analysed relative percentage contributions are a result of the set of data used in the study. Changes in the mix of variables for the internal and external constraints would probably lead to different result. Thus, rather than being indicators of relative contributions on quantitative terms, the findings show that the internal constraint factors have weightier impact on productivity than external factors.

The finding that the project management approach has the highest impact on onsite labour productivity concurs with the findings in previous studies (Knutson et al. 2009; Burati et al., 1992) that the way a project is managed, especially as it relates to the critical path and critical cost activities, is key to productivity and performance. However, a number of authors (Mbachu, 2008; Henriod and Lantran, 2000) believe that positive net cash flow, being the lifeblood of the industry and the source of project finance, has the most profound impact on productivity and performance. 


\begin{tabular}{|c|c|c|c|c|c|c|c|c|}
\hline \multirow{3}{*}{$\begin{array}{l}\text { Broad categories of internal and } \\
\text { external constraints }\end{array}$} & \multicolumn{5}{|c|}{${ }^{\text {a Level of impact }}$} & \multirow{3}{*}{${ }^{\mathrm{b}} \mathrm{TR}$} & \multirow{3}{*}{${ }^{\mathrm{c}} \mathrm{MR}$} & \multirow{3}{*}{$\begin{array}{l}\text { RII } \\
(\%)\end{array}$} \\
\hline & VH & $\mathbf{H}$ & $\mathbf{M}$ & $\mathbf{L}$ & VL & & & \\
\hline & 5 & 4 & 3 & 2 & 1 & & & \\
\hline $\begin{array}{l}\text { 1) Project management/ project team } \\
\text { characteristics }\end{array}$ & 17.14 & 40.00 & 28.57 & 11.43 & 2.86 & 35 & 3.57 & 14.14 \\
\hline 2) Project finance & 14.71 & 50.00 & 17.65 & 11.76 & 5.88 & 34 & 3.56 & 14.09 \\
\hline 3) Workforce & 11.76 & 44.12 & 32.35 & 8.82 & 2.94 & 34 & 3.53 & 13.97 \\
\hline 4) Project characteristics & 2.94 & 41.18 & 41.18 & 14.71 & 0.00 & 34 & 3.32 & 13.16 \\
\hline 5) Unforeseen events & 11.76 & 14.71 & 38.24 & 29.41 & 5.88 & 34 & 2.97 & 11.76 \\
\hline 6) Technology/ process & 0.00 & 18.18 & 57.58 & 24.24 & 0.00 & 33 & 2.94 & 11.64 \\
\hline 7) Statutory compliance & 0.00 & 20.59 & 47.06 & 26.47 & 5.88 & 34 & 2.82 & 11.18 \\
\hline $\begin{array}{l}\text { 8) Other external forces (economic, } \\
\text { political, industry, etc) }\end{array}$ & 3.03 & 6.06 & 39.39 & 45.45 & 6.06 & 33 & 2.55 & 10.08 \\
\hline
\end{tabular}

Table 10 Relative levels of impact of the broad categories of onsite productivity constraints

Notes: a) Levels of Impact: VH = Very high (5), $\mathrm{H}=$ High (4), $\mathrm{M}=$ Medium (3), L = Low (2), VL = Very low (1). b) $\mathrm{TR}=$ Total responses; $\mathrm{c}$ ) MR = Mean rating (see Equation 2).

\section{Conclusions}

This study, as part of its key aim, has identified the key on-site labour productivity constraints in the New Zealand construction industry and has prioritised the constraints based on their relative levels of impact. 56 sub-factors have been identified under 8 broad categories of internal and external constraints. Compared to the external factors, the internal constraints were found to contribute far more to the onsite labour productivity issues in the New Zealand construction industry. In the order of decreasing influence, the internal factors comprise project management, project finance, workforce, project characteristics and technology/ process. The key subcomponents under each of the five broad categories of the internal constraints are rework; level of skills and experience of the workforce; adequacy of method of construction; buildability issues; and issues around coordination, supervision and performance monitoring and control; respectively. Under the three external constraint broad categories, the key subcomponents are compliance with the Resource Management Act 1991; ground conditions; and the boom-bust cycles, market conditions and level of competition in the industry; respectively. In addition to understanding the nature of the identified constraints, some mitigation measures have been discussed for addressing the key subcomponent under each broad constraint category.

In conclusion it is believed that by focusing on the relative levels of impact of the identified constraints, the project team could be guided well in their efforts to addressing the constraints in a cost-effective manner.

\section{Recommendations for Future Studies}

This study focused on constraints to construction on-site productivity; however, there are several aspects to construction productivity. Future studies should explore other influencing factors affecting construction productivity at all stages of the procurement process.

As demonstrated in the demographic analysis of the respondents, the responses were largely from contractors and project management consultants. The results did not include many inputs from subcontractors who provided only 8 percent of the responses. It may be necessary to aim for representative feedback from subcontractors in future studies, as they are the key players on construction sites. Also there was absence of feedback from clients and designers. Further studies should also seek to capture opinions of these stakeholders as they significantly influence on-site procurement processes and performance outcomes. 


\section{Acknowledgement}

The work reported here was funded by the Building Research Association of New Zealand (BRANZ) through the Building Research Postgraduate Scholarship, for which the authors are grateful.

\section{References}

Abdul Kadir, M.R., Lee W.P., Jaafar M.S., Sapuan S.M. and Ali A.A.A. (2005) 'Factors affecting construction labour productivity for Malaysian residential projects" Structural Survey, 23 (1), 42-54

Alinaitwe, M.H., Mwakail, J.A. and Hansson, B. (2007) 'Factors affecting the productivity of building craftsmen: Studies of Uganda', Journal of Civil Engineering and Management, XIII (3), 169-176

Building and Construction Sector Productivity Taskforce (BCSPT) (2009) 'A modern efficient and productive New Zealand built infrastructure industry'. Report of the Building and Construction Sector Productivity Taskforce, Department of Building and Housing, Wellington, New Zealand

Burati, J.L., Farrington, J.J. and Ledbetter W.B. (1992) 'Causes of quality deviations in design and construction', ASCE Journal of Construction Engineering and Management, 118 (1), 34-49

Carlos, C. and Paul, D. (2010) 'Effortless productivity tracking', White Paper \#21, Breakthrough Strategy Committee, London, UK, Accessed 08 February 2011 from:

https://www.construction-institute.org/scriptcontent/btsc-pubs/CIl-BTSC-121.doc

Chang, C. and Ive, G. (2002) 'Rethinking the multi-attribute utility approach based procurement route selection technique', Construction Management \& Economics, 20 (3), 275-284

Clayton, C.R.I. (2001) Managing Geotechnical Risk: Improving Productivity in UK Building and Construction, $1^{\text {st }}$ edition, Thomas Telford, London

Construction Strategy Group (CSG) (2010) Why is this Industry Important to New Zealand and New Zealanders?, Accessed 10 March from

http://www.constructionstrategygroup.org.nz/industry.php

Cooper, D.R. and Schindler, P.S. (2006) Business Research Methods, $9^{\text {th }}$ Edition, McGrawHill/Irwin, New York

Cooper, K.G. (1993) 'The rework cycle: benchmarking for the project manager'. Project Management Journal, 24 (1), 17-22

Davis, N. (2008) 'Building and Construction Sector', Summary Report, Accessed 08 December 2010 from:

http://www.dbh.govt.nz/UserFiles/File/Building/sectorforum/Draft\%20Summary\%20Productiv ity\%20Report\%20for\%20Forum.doc

Department of Building and Housing (DBH) (2009) Report of the Building and Construction Sector Productivity Taskforce, Accessed 20 October 2010 from:

http://www.dbh.govt.nz/UserFiles/File/Building/sector-forum/Sector-Productivity-TaskforceReport.pdf

Department of Building and Housing (DBH) (2008) Briefing for the Minister of Housing. Wellington: Department of Housing, (November), Accessed 10 March 2010 from http://www.dbh.govt.nz/UserFiles/File/AboutUs/Strategic-Direction/pdf/BIM-housingnov08.pdf

Duncan, J.R. (2002) 'Innovation in the building sector: Trends and new technologies', Conference paper No. 95, IPENZ Convention, Wellington, 25 March, 1-9 
Egan, J., (1998) 'Rethinking construction'. Report of the Sir John Egan's Construction Task Force (July), London: HMSO

Enshassi, A., Mohamed, S. Mustafa A.Z. and Mayer, P.E. (2007a) 'Factors affecting labour productivity in building projects in the Gaza Strip', Journal of Civil Engineering and Management, XIII (4), 245-254

Enshassi, A., Mohamed, S., Mayer, P. and Abed, K. (2007b), 'Reflective practice: Benchmarking masonry labor productivity', International Journal of Productivity and Performance Measurement, 56 (4), 358-368

Fabling, R. and Grimes, A. (2008) 'The "suite" smell of success: Complementary personnel practices and firm performance', Discussion Paper DP2009/13, Reserve Bank of New Zealand, Wellington, (December), Accessed 10 March 2011 from

http://www.rbnz.govt.nz/research/discusspapers/dp09 13.pdf

Henriod, E.E. (2010) 'An experience raising productivity', Constructing New Zealand, Issue 14 (February), 10-11

Henriod, E.E. and Lantran, J.M. (2000) 'Trends in contracting practice for civil works', Site Resources, World Bank, New York, 1-9

Jarkas, A.M. (2010) 'The effects of buildability factors on rebar fixing labour productivity of beamless slabs', Australasian Journal of Construction Economics and Building, 10 (1/2)

Jergeas, G., (2009) 'Improving construction productivity on Alberta oil and gas capital projects'. A Report Submitted to: Alberta Finance and Enterprise, University of Calgary, Accessed 25 February 2011 from:

http://www.alberta-canada.com/documents/Improving Construction Productivity.pdf

Kazaz, A., Manisali, E. and Ulubeyli, S. (2008) 'Effect of basic motivational factors on construction workforce productivity in Turkey', Journal of Civil Engineering and Management, 14 (2), 95-106

Knutson, K., Schexnayder, C.J., Fiori, C. and Mayo, R.E. (2009) Construction Management Fundamentals, $2^{\text {nd }}$ Edition, McGraw-Hill, New York

KPMG (2009) 'Managing construction risk', A White Paper on Industry Perspectives and some Recommendations, Audit Committee Institute, KPMG International, (March), 1-8

Lam, P. and Wong, F.W. (2009) 'Improving building project performance: How buildability benchmarking can help', Construction Management and Economics, 27 (1), 41-52

Lam, P., Chan, A., Wong, F.K. and Wong, F.W. (2007) 'Constructability rankings of construction systems based on the analytical hierarchy process', ASCE Journal of Construction Engineering and Management, 13 (1), 36-43

Leedy, P.D. and Ormrod, J.E. (2009) Practical Research: Planning and Design, $9^{\text {th }}$ Edition, Pearson Education, Upper Saddle River, New Jersey

Love, P. and Li, H. (2000) 'Quantifying the causes and costs of re-work in construction', Construction Management and Economics, 18, 479-490

Love, P., Mandal, P. and Li, H. (1999) 'Determining the causal structure of re-work influences in construction', Construction Management and Economics, 17, 505-517

Mbachu, J. (2008) 'Conceptual framework for the assessment of subcontractors' eligibility and performance in the construction industry', Construction Management \& Economics, 26 (5), 471-484

Mbachu, J. and Nkado, R. (2007) 'Factors constraining successful building implementation in South Africa', Construction Management and Economics, 25 (1), 39-54

McCullouch, B. (2007) 'Automating field data collection in construction organizations'. Proc., 5th Construction Congress: Managing Engineered Construction in Expanding Global Markets, Minneapolis, 957-963

Durdyev, S and Mbachu, J (2011) 'On-site labour productivity of New Zealand construction industry: Key constraints and improvement measures', Australasian Journal of Construction Economics and Building, 11 (3) 18-33 
McShane, O. (1996) 'The impact of the resource management act on the "Housing and Construction" Components of the Consumer Price Index', A Report Prepared for the Reserve Bank of New Zealand, Accessed 26 February 2011 from: http://www.rmastudies.org.nz/documents/ResBankF.pdf

Mojahed, S. and Aghazadeh, F. (2007) 'Major factors influencing productivity of water and wastewater treatment plant construction: Evidence from the deep south USA'. International Journal of Project Management, 26 (2008), 195-202

Oglesby, C., Parker, H., and Howell, G. (1989) 'Productivity Improvement in Construction', New York: McGraw-Hill Book Company

Page, I.C. (2010) 'Construction industry productivity', Study Report SR 219, Building Research Association of New Zealand (BRANZ), Wellington, New Zealand

Saghatforoush, E., Hasim, S., Jaafar, M., and Abdul Kadir, M. (2009) 'Constructability implementation among Malaysian building contractors'. European Journal of Scientific Research, 29 (4), 518-532

Sanders, S. R. and Thomas, H. R. (1993) 'Masonry productivity forecasting model', Journal of Construction Engineering and Management, ASCE, 119 (1), 163-179

Thomas, H. R. and Sakarcan, A. S. (1994) 'Forecasting labor pro- ductivity using factor model'. Journal of Construction Engineering and Management, ASCE, 120 (1) 228-239

Tran, V and Tookey, J. (2011) 'Labour productivity in the New Zealand construction industry: A thorough investigation', Australasian Journal of Construction Economics and Building, 11 (1), 41-60

Wilkinson S and Scofield S,(2010), Management for the New Zealand Construction Industry, 2nd Edition, Pearsons 